\title{
The Implementation of Inpatient Identification In Hospital X Yogyakarta
}

\author{
Totok Sundoro* \\ *Program Studi Kesehatan Masyarakat, STIKes Surya Global Yogyakarta \\ Email: totoksundoro@gmail.com
}

\begin{abstract}
Hospital should be able to provide the sense of secure and safety towards the effect of services that have been provided as an effort to fulfill the quality standards and the community rights towards the qualified service. Hospital patient safety is a system where the hospital makes the patient care safer. One of patient safety services can be started from the accuracy of patient identification. The observation results show that there is incompatibility in its implementation. This study aims to determine the implementation of the inpatient identification at RSUD Kota Yogyakarta using The National Standard for Hospital Accreditation Edition 1 with qualitative descriptive method by using interview guidelines and observation sheets as the instruments of this study. The interview was conducted with the hospital directors, nurses, head room, doctors, medical record staffs, and patients. Direct observation related to the implementation of patient identification was conducted in the hospital. The results show that the implementation of the inpatient identification in the hospital has been implemented well. Based on the results of regulation search, interview, documentation and simulation, it shows point 55 (91.67\%) where it means completed. There is a policy that regulates the findings based on the staff incompatibility and the limitation of identity label. It is required an effort to build patient safety culture in the hospital through supports from the directors, supervisor, training and socialization, as well as the fulfillment of
\end{abstract}

supporting infrastructure and motivation to the officers.

Keywords: Patient Safety, Patient Identification, Safety Culture

\section{INTRODUCTION}

Hospital is a health service institution that carries out complete individual health services that provides inpatient, outpatient and emergency services. Being able to provide excellent service to the patients, hospital is required to have effective leadership ${ }^{1}$. Hospital must be able to provide protection towards patient safety, community, hospital environment, as well as the existing human resources; to direct all hospital service activities so that being able to provide services that fulfill quality standards and guarantee a sense of security and protection against the impact of services provided in the context of fulfilling community rights to quality and safe services ${ }^{2}$.

Hospital patient safety is a system where the hospital makes patient care safer including risk assessment, identification and management of matters related to patient risk, report and analysis of incidents, the ability to learn from incidents and their follow-up, and implement solutions to minimize risks and prevent injuries caused by errors caused by carrying out an action or not taking the unnecessary action ${ }^{3}$. Errors due to incorrect patients identification of patients can occur in almost all aspects or stages of diagnosis and treatment. Misidentification of patients can occur to anesthetized patients, disoriented patients, unconscious patients, patients who 
exchange beds/rooms/locations in the hospital, sensory abnormalities, or due to other situations ${ }^{4}$.

The accuracy of patient identification is one of service safety systems in the hospital. By doing misidentification, it can lead to many errors occurred. Based on the data obtained from Hospital "X", there were 171 cases of patient safety incidents in 2009-2011 where $65.5 \%$ cases were related to mistaken identity (for example mistaken laboratory results and others). There were approximately $60 \%$ incidents occurred in the inpatient ward 5.

Siti Aisyah Islamic Hospital Madiun, which is one of the referral hospitals in Madiun area that provides 24-hour-patient services in a day, also occurs KTD where there is a misidentification made by hospital officers. Data on patient safety incidents in 2012 reported an analysis of the incident causes of $46 \%$ related to misidentification, $36 \%$ due to ineffective communication resulting in medication errors, $18 \%$ due to procedures not being carried out ${ }^{6}$.

Hospital must ensure that the patient identification process runs well since the patient was registered for the first time ${ }^{7}$. Based on the preliminary study, it was found that the staff who delivers the food did not conduct patient identification first while turnover the food to the patient. In the form of radiology examination result, the patient's date of birth was not mentioned. It means that the staff had not applied the identification procedure correctly and fill the identity based on the hospital accreditation standard rules that accommodate three identity namely patient's full name, patient's medical record number, and patient's date of birth. Because of the hospital importance in providing safe services in the implementation of inpatient identification correctly in the hospital, so the researchers evaluate the implementation of inpatient identification at RSUD Kota Yogyakarta.

\section{MATERIAL AND METHOD}

This research is a kind of descriptive research with a qualitative approach on the implementation of inpatient identification in hospitals. Patient identification is an effort to find out the patient's identity through ID numbers (ID card/Driving license/student cards/ college student cards) and birthmarks to facilitate the service provision to patients ${ }^{8}$.

There were 15 (fifteen) people who ran the interview. The major informant is the hospital staffs while the supporting informants are the director of the hospital and the patients. This sample is chosen to know directly the implementation of identification by the hospital staff to the patient and to ensure the correctness of the implementation of patient identification that has been carried out by the hospital staff to the patient. The hospital directors are involved as the informant in that the researchers can seek for deeper information related to the the director's effort in building patient safety culture in the hospital. The research was conducted in RSUD Kota Yogyakarta.

There are several data processing techniques used in this study, namely editing, classification, and coding. The data analysis method uses data reduction through the selection process by focusing on the simplifying, abstracting, and transforming raw data that appear from the field written record. The research variable is the implementation of inpatient identification. The sample is selected by using purposive sampling method. This research is carried out based on the Certificate of Ethics Eligibility from the Health Research Ethics Committee of RSUD Kota Yogyakarta Number 28/KEP/RSUD/IV/2020 dated April 30th, 2020. The research was conducted in AprilMay 2020.

\section{RESULT AND DISSCUSION}

Researchers carry out the process of collecting data to determine the aspects of regulation, implementation and obstacles in implementing the inpatients identification in the hospitals. Furthermore, Table 1 shows how to determine the characteristics of research subjects.

There are two kinds of informant characteristics (hospital staffs), namely 5 
(five) male informants and 5 (five) female informants. There are 7 (seven) people with ages 36-45 years old and 3 (three) people with ages 46-55 years old. From the educational background, there are 1 (one) person with Graduate Degree (S2), 4 (four) people) with Undergraduate Degree (S1), and 5 (five) people with 3-year Associate Degree (D3). From the informant characteristics (patients), there are 5 (five) people with Senior High School (SMA) background including 1 female patient while there are 4 (four) informants with 3-year Associate Degree (D3).

\section{The Results of Regulation Analysis on the Implementation of Patient Identification}

The researchers conduct a direct observation and look for the evidence related to the regulation on the implementation of patient identification in the hospital. The hospital has established the regulations for the Implementation of Patient Safety Targets in the Hospital in the Decree of Director Number 445/108/KPTS/I/2019 related to the policy for the Implementation of Patient Safety Target at RSUD Kota Yogyakarta and Standard Operating Procedures (SOP) Number: 14.323.01.0120 related to Patient Identification, SOP Number: 14.323.1425 related to Identification of identity bracelet allergy patient, SOP Number: 14.323.1111 related to Identification of patients who are unable to wear identity bracelet, SOP Number: 14.323.01.0125 related to Fitting and removing of patient identity bracelet , SOP Number: 14.323.1389 related to Fitting of patient identity bracelet who pass away in Emergency Unit, SOP Number: 14.323.01.0126 related to Identification of newborn baby, SOP Number: 14.323.01.0127 related to Identification of newborn baby referral outside of RSUD Kota Yogyakarta , SOP Number: 14.323.01.0128 related to Identification of problematic baby's mother, SOP Number: 14.323.01.0124 related to Patient Identification before blood donor/blood product or blood transfusion, SOP Number: 14.323.01.0122 related to Patient Identification before blood draw and specimens for clinical examination, SOP
Number: 14.323.01.0123 related to Identification before carrying out invasive procedures, SOP Number: 14.323.01.0121 related to Identification before medicine administration.

\section{The Result of Inteview Analysis on the Implementation of patient identification}

The research is begun with the data collecting process by using interview methods. The summary of the interview informs that the officers are able to provide a good description related to the time when to put the patient's bracelet on. The procedure begins by fitting the bracelet suitable with the patient's condition, explaining the purpose and benefits of fitting the identity bracelet and conveying the time the patient is identified in the ward. The hospital staff always confirms to the patient to answer 2 (two) things, namely the patient's name and date of birth. This confirmation is always carried out while the patient is in the ward when doing medical treatment, administering medicine, dieting so that there is no error in the patient when the nurse gives action or administering medicine during the treatment period.

This research is begun through the process of collecting data by using interview method that aims to know how the staffs put on the identity bracelet, its function, and when the patient identification is carried out. Here are the following interview citation from 5 (five) informants.

\footnotetext{
"Greeting, introduction, put on the identity bracelet by explaining the function and purpose, ensure the patient family understands................carried out by ensuring the patient data correctly to get service and treatment as long as the patient stays in the hospital. It is carried out before giving the medicine, before the action or before delivering the food". (Staff 1)

"Deliver the purpose why the bracelet is put on,
the bracelet is put on based on the terms and
condition, conducted by requesting the patient
to mention his name and date of birth or by
looking at the bracelet itself...for the the
benefits... to avoid handling the wrong patient
while the nurse provides the nurse action or
give the medicine. This identification is carried
} 
out before the action, such as taking the blood, put in an IV, and giving the medicine". (Staff2)

"Greeting, give the bracelet to the patient by explaining that the patient identity will be matched first with the bracelet before performing dialysis or giving the medicine to ensure for the truth... then the benefit is to match between the patient identity and the action while taking the blood, giving the medicine or surgery". (Staff 3)

"Put on the identification bracelet on the patient wrist. The function is to ensure the validity between the data and the patient so the patient will get service, action, and treatment as long as the patient becomes the inpatient. After the patient stays in ward, the ward staff will always confirm for the patient identity by requesting patient to mention his name and date of birth". (Staff 4)

"The bracelet is put on, then explained that no need to put off the bracelet before the patients is allowed to leave and to inform that the staff will match the identity on the bracelet by confirming the data while the benefit is to avoid the mistaken action towards the patient. The staff will identify the patient before giving the medicine, IV, and other actions, for example taking blood". (Staff 5)

Triangulation Credibility Test Results Sources of questions about "Information when fitting patient identity bracelets" were carried out by hospital staff. All informants gave relatively the same answers, where the staff put on a bracelet with a greeting,starting with introducing the hospital staff to the patient and family, then placed the patient's identity bracelet on the patient's wrist by conveying the intent and purpose of the bracelet, namely the bracelet fitted according to the conditions, and also to ensure the correct identity of patients in getting service measures such as dialysis, or administration of medicine and medication during hospitalization. Furthermore, the staff ensures that the patient or family understands that after the patient is in the inpatient room, ward staff will always confirm the patient's identity by asking the patient to mention his name $\&$ date of birth or match by looking at the bracelet worn and delivered not to remove the identity bracelet before the patient is being allowed to go home.

Question on "Function of patient bracelet and when the patient identity is asked". The hospital staff explains that the patient bracelet functions to ensure and match the patient identity to get service, action or treatment delivered by the hospital staff. Beside that, it is an accreditation rule which is compulsory to do in order to prevent the patient error in giving action and treatment as long as the patient stays in the hospital. All informants are able to provide answer on the implementation of patient bracelet fitting and provide explanation on the function of patient bracelet as well as the time to perform patient identification during treatment. On the whole, the score achievement is 10 which means completely fulfilled/well done.

The next research is to run the interview with the patients related to the implementation of patient identification carried out by the hospital staff. The purpose is to get some information from the patient related to the staff obligation where the staff needs to explain the benefit of patient bracelet and to ensure that the patient/family understands the reason why the staff always identify the patients before do the action in the hospital. The interview citation is as follows:

\footnotetext{
"Yes, it is explained...." (Patient 1)

"mmm... it seems that the staff has not explained the benefit...mmm...but the staff asks for my identity when the staff wants to give the medicine or put an IV". (Patient 2)

"It is informed ... and always asked from the name and date of birth...then the nurse matches with the identity bracelet...."(Patient 3)

"Yes, it is informed...but the staff does not always asks me about my identity (Patient 4)

"Yes, it is informed...but the nurse often sees the bracelet". (Patient 5)
}

Based on the patient trace, it can be informed that not all hospital staffs explain the function of patient bracelet when the hospital staff puts on the identity bracelet to 
the patient and not all implementations are carried out by identifying the patient as if the mealtime. From the result of Credibility Triangulation Source test on "hospital staff explains the benefits of bracelet fitting", it is obtained answers from 5 (five) informants in which the 3 (three) of them answered "Yes" means the hospital staff explains the benefits of the patient's identity bracelet when fitting it to the patient. Then 1 (one) informant answered "No" means the hospital staff does not explain the benefits of the patient's identity bracelet when fitting it. There is 1 (one) informant replies that the hospital staff does not explain the benefits of the patient's identity bracelet when fitting it, but it is explained by hospital staff in the ward/treatment room. It means that not all hospital staffs provide information on the benefits of patient's identification.

Question 2 (two) is about "before administering medicine, actions, blood draw / blood products, taking samples on the hospital staff who asks the patient's identity". It is obtained that the answers from the 5 (five) informants, 3 (three) informants give answers "Yes" that means the hospital staff identifies the patient when administering medicine, actions, blood draw / blood products, and taking samples. There is 1 (one) informant who answers "Not Always" and 1 (one) informant identifies by looking / matching on the identity bracelet but not mention verbally.

The results of the assessment score of interviews with patients on the implementation of identification conclude that the results of the acquisition of an average value show 5 (five) meaning that it is partially achieved or not well implemented in the implementation of inpatient identification in RSUD Kota Yogyakarta.

\section{The Result of Analysis on The Implementation of The Patient Identification}

The first document conducted which is related to assessment element requires that

"patient identity in all medical record should be printed three times use three different identities, namely patient identity as mentioned in E-ID, date of birth and medical record number."

The results of the document search informs that from 10 medical record identity documents there are $5(60 \%)$ documents declared complete and $4(40 \%)$ partially complete. From the non-filled form, the complete identity is on the patient's birth date on the inpatient cover sheet, integrated development record, radio-diagnostic / ultrasound examination results and CT Scan results.

In the completeness of identity contents of $10(100 \%)$ medicine label identity and prescription have been fully completed. In the completeness of identity content of 10 documents from the laboratory / radiology examination to fill in the identity of the results of the laboratory examination, there are 5 completed sheets, but on the radiodiagnostic / USG examination results / CT Scan the results can not be declared complete for the component contents of the patient's date of birth. The results of the document search for the completeness of contents identity show that there are 10 complete documents $(100 \%)$ for its food identity contain of patient identity, date of birth, and medical record number.

From the completeness of identity contents on the medicine label, prescription and food label, it is obtained that complete results with a score of 10 (ten), while for the completeness of the identity contents on the sheet of each medical record and the results of the laboratory/ radiology examination partially fulfilled with a score of 5 (Five). Overall, for the contents of the patient's identity in all medical record files, a score of $10(80 \%)$ means that it is completely fulfilled.

\section{The Result of Analysis on the Implementation of Inpatient Identification}

Observation activities are carried out to determine the scoring based on the assessment elements of assessment that requires

\footnotetext{
"Implementation of the patient identity before the action, diagnostic and therapeutic
} 
procedures, before administering medicine, blood, blood products, taking specimens and dieting and identification using a minimum of two identities from three patient identities through verbal or visual identification"

The result of the observations is informed for the actions before medicine administration, blood collection and overall specimens as many as $10(100 \%)$ procedures are performed for patient identification, for actions before blood transfusion $3(100 \%)$ are overall for patient identification. However, for the service of providing the dieting, there are 3 (three) of 10 (ten) patients have not run the patient identification procedure. It is concluded that not all health staffs carry out regulations in inpatients identification.

The result of the observational analysis recapitulation on the implementation of the patient identification system explains that the implementation of patient identification is carried out before administering medicine, blood, blood products, specimen collection, and dieting with a score of 10 (ten) for the assessment of 4 (four) elements that are completely fulfilled while 1 (one) ) element, namely dieting, is partially completed.

The following observations are related to the assessment element which requires that "Implementation of the patient's identity before the action, diagnostic and therapeutic procedures, before administering medicine, blood, blood products, taking specimens and dieting and identification using at least two identities of the three patient identities through verbal or visual identification".

Based on the results of the observational analysis, it is informed that from 10 implementations of patient identification before administering intravenous fluids to the patient, the nurse has identified verbally and visually where the hospital staff asks the patient's name and patient's date of birth then matches it on the identity bracelet. In the prehemodialysis service, the implementation of patient identification is not carried out well.

Observational activities in 10 (ten) actions before blood draw and / or before taking specimens as a whole are $100 \%$ completed. Then for 10 (ten) actions before the overall radiology diagnostic procedure is $100 \%$ completed. The results of observational analysis on the implementation of patient identification of patient in coma are identified visually by matching the identity on the patient's bracelet.

The results of the observational recapitulation on the implementation of the inpatient identification, it is informed that the implementation of identification before the administration of intravenous fluids, before blood draw and specimens as well as before the radiological procedures and before the identification of patients in coma from the activities of 10 (ten) observations is stated to be fulfilled completely (Score $10 /$ ten). It means that it has been carried out well in the implementation of identification of inpatients in the hospital. From the results of the search for regulation, interviews, documentation and simulations, it is informed that the achievement of the implementation of inpatient identification in RSUD Kota Yogyakarta is obtained a score of 55 $(91.67 \%)$ meaning that overall the implementation of patient identification in the hospital has been carried out well (completely fulfilled).

Focus Group Discussion (FGD) is carried out to know the staff answer who becomes the informant in this research related to the responds of accreditation, score achievement respond, carrying capacity, hospital commitment and recommendation from the problems encountered. Here are the interview citations through FGD related to respond about accreditation.

"It is very important to provide better service" (Staff 1)

"It is very important" (Staff 2)

"It is important so the staff is able to keep his performance and provide the service based on the standard". (Staff 3)

"It is very important to do so that the patient will be satisfied and the service is qualified". (Staff 4)

"It is very important.... with accreditation, there will be safety quality in the hospital". (Staff 5) 
The result of informant interview citation about score achievement $91.67 \%$ in this study:

"It is good but it should be maintained or improved". (Staff 1)

"Yes...Alhamdulillah Hopefully it will be better again”. (Staff 2)

"Hopefully it will be better again and motivate us to work". (Staff 3)

"If it is possible, the score should be increase more and more". (Staff 4)

"It should be maintained. Don't lower the score". (Staff 5)

The result of informant interview citation about the success on the implementation of patient identification, as follows:

"it is often carried out by socializing continuously then supported from the management". (Staff 1)

"The Human Resource support as the supervisors should run well, then the support on material and equipment depend on the availability of hospital budget, such as identity label, identity bracelet”. (Staff 2)

"It should be carried out continuously, then there should be reward or recreation for the staffs to motivate the staffs". (Staff 3)

"Being active to do training that function to refresh, as an evaluation from the direction or management". (Staff 4)

"For me, the main support is from the hospital director". (Staff 5)

The result of informant interview citation related to the hospital commitment to apply the patient safety target especially patient identification, as follows:

\footnotetext{
"Yes, already committed". (Staff 1)

"Really committed". (Staff 2)

“Committed, but not optimal yet". (Staff 3)
}

"Committed, the leader is already good". (Staff

4)

“Committed”. (Staff 5)

The result of informant interview citation related to obstacles encountered in apllying the patient identification in the hospital, as follows:

"The limitation of identity label, lack of supervision, from medical record design or IT and not understand yet or forget the rules". (Staff 1)

"The label runs out and need more supervision" (Staff 2)

“Still underestimate and no risk". (Staff 3)

"Perhaps lack of supervision and evaluation, no sanction". (Staff 4)

"Less commitment from the hospital staff and no warning". (Staff 5)

The result of informant interview citation related to recommendation from the problems encountered in applying the patient identification in the hospital, as follows:

\footnotetext{
"The label supply is adequate, improving the supervision at least by IPCN or head room, coordinating with the medical record and IT". (Staff 1)

"Label supply and involving the role of head room". (Staff 2)

"socializing how important identification is and provide sanction”. (Staff 3)
}

"Socialization and need to be supervised". (Staff 4)

"Often conduct monitoring and give a warning or sanction tho those who disobey". (Staff 5)

The interpretation result from interviews through FGDs inform that hospital staffs consider that accreditation is important and needed to be carried out by hospitals so that the hospital can provide qualified service, staffs are able to provide services in accordance with patient safety standards which ultimately impact on patient 
satisfaction. Hospital staffs give a very good response from the achievement score assessment results of researchers. The staffs hope that this achievement can be maintained or even be better.

Based on the hospital staffs' opinion, the achievement of high scores for hospitals cannot be separated from the support of several parties, such as support from the Director and the management who have been very good by providing support through the provision of human resources in charge of conducting supervision, providing supporting infrastructure such as bracelets and labels then conducting training and technical socialization of patient identification for hospital staff concerned. Other support is the existence of rewards through employee recreation. The hospital is committed to achieve accreditation and provide safe services for patients, but it is less than optimal so that there are still discrepancies in the implementation. Some obstacles related to non-compliance in the implementation of patient identification are due to lack of staff commitment, the availability of identity labels, supervision or monitoring of implementation by IPCN or the Head of Room which is considered to be lack and there is no sanction for non-compliance in the implementation of patient identification. For the problem of incomplete identity design content, the medical record design staff / IT staff does not understand the rules or forget the rules.

Hospital staffs advise management to provide identity labels to ensure there are no shortages, re-socialize to hospital staff about the implementation of patient safety targets, actively involve the appointed IPCN or the head of the room in supervising implementation in the ward. Related to the incomplete identity design, it will be coordinated with the medical records and Information technology (IT).

To realize the fulfillment of patient safety standards in hospitals, especially the implementation of correct identification by hospital staffs, RSUD Kota Yogyakarta has set regulations on the implementation of inpatient identification in Director's Decree Number: 445/108 / KPTS / I / 2019 dated on January 31, 2019 regarding on the Implementation of Patient Safety Targets in RSUD Kota Yogyakarta. In this policy, there are 12 (twelve) Standard Operational Procedures (SPO) for the Implementation of Patient Identification in RSUD Kota Yogyakarta.

The implementation of patient safety targets in RSKIA PKU Muhammadiyah Kotagede Yogyakarta can be realized if the hospital management compiles the policy direction and is equipped with phasing as a guide to be carried out by staffs while providing services to the patients in the hospital9.

Based on the results of research conducted on the implementation of correct inpatient identification, it is informed that the hospital obtains an achievement score with a value of $55(91.67 \%)$ meaning that it is fulfilled completely or a policy/implementation process has been made and implemented. However, in the process of implementation, there are still discrepancies such as there are staffs who do not identify the patient before administering the medicine and dieting, do not fill in the complete medical record identity which contain the patient's name, date of birth and medical record number and there is still a medical record form without patient's date of birth.

Good support from the Director and management through the provision of human resources in charge of carrying out supervision, providing supporting infrastructure such as bracelets and labels then conducting training and technical socialization of patient identification for hospital staff concerned. Other support is in the form of reward through employee recreation.

Hospital staff advise management on non-compliance of staffs in carrying out patient identification procedures before the service is provided by building a safe service culture through supervision by the Head of Room and/or by the IPCN Staff or the staff who is appointed for it. It is expected that the 
supervision activities can motivate employee performance.

In improving the implementation of patient safety culture conducted by nurses can be done with supervision for the implementation of patient safety on an ongoing basis ${ }^{10}$. The inculcation of safety culture values can be performed formally or informally, installing symbols, slogans and posters related to patient safety programs, training (for changing knowledge (cognitive), attitude (affective), behavior (psychomotor), organizational learning ${ }^{11}$.

Evaluation on the Implementation of the Patient Identification System in the Hospital Inpatient Installation is conducted with the purpose to know the causes of the nonoptimal implementation of the patient identification system and to find alternative solutions to optimize the implementation of the patient identification system in the Inpatient Room of X Hospital in Malang. This research was conducted using data collection methods through focus group discussions (FGD), interviews, observations and study documents. To identify alternative priority solutions, it is used brainstorming by considering urgency, severity / seriousness. The results of the study stated that the main cause of the non-optimal implementation of the patient identification system is related to the supervision system of the implementation of identification procedures that have not been optimal and the safety culture that still needs to be improved ${ }^{12}$.

To embody an attitude into a real deed, it takes a supporting factor or a condition that allows, among others, namely motivation ${ }^{13}$. Nurses are motivated in implementing a procedure when they are evaluated individually or according to fairness with the rewards that nurses receive in proportion to what they do. Nurses who receive awards, according to their roles, improve nurses' work motivation to be more inclined to carry out the procedure correctly and continuously ${ }^{14}$.

Then the management thinks that it is necessary to re-socialize to the staff about the patient safety target policies, especially the correct patient identification procedure and the purpose of the procedure. Writing the identity on the medical record form is sometimes done manually which finally causes the incomplete filling of medical record sheet or blood sample label, such as the patient's birth date. The reason is the limitations or lack of identity labels provided or printed by inpatient registration staffs. The solution is to ensure there is no lack of identity labels supply. Regarding the problem of identity content mismatches on the forms, the management can immediately coordinate with related parties such as the Medical Records Section, Information Technology (IT) Section and related services to revise the design of the medical record form and at the same time re-socialize it to the relevant staffs. The results of this study are in accordance with the theory that a person who has more sources of information obtains wider knowledge. Professional staffs need to educate their staff about the importance of patient safety based on national and international standards and tried to be a culture in implementing applicable procedures. The point is that education needs to be given in this case such as training and counseling to nurses related to patient safety so that nurses can carry out or be obedient with actions that refer to patient safety ${ }^{15}$.

Research on the Development of the Function and Role of Room Heads in Prevention and Control of Infection in Hospital X was conducted with the purpose of describing the function and role of karu in PPI at RS X Jakarta. The results of the literature study show that the role of nurses as karu staff in the ward that carries out nursing care to patients has great opportunity to increase the success of infection control ${ }^{16}$.

It can be concluded that the incompatibility in the standard implementation and procedures of inpatient identification in the hospital can be followed up with the support of hospital leaders or management through the inculcation of patient safety culture values by conducting socialization/training, supervision or monitoring that involve the Head of Room or 
PPI Nurse (IPCN) as well as infrastructure support.

\section{CONCLUSION}

The implementation of inpatient identification in the hospital has been run well. Based on the regulation, interview, documentation, observation and simulation, the achievement score is $55(91.67 \%)$ which means completed. There is a policy that manages, yet still found the mismatch in the implementation because of the staffs' disobedient so several medical record sheets are not completed as the standard. Besides, there is also limitation of identity label. It is needed an effort to build patient safety culture in the hospital through director support, control, and supervision, fulfillment of supporting infrastructure and giving motivation to the staffs.

\section{ACKNOWLEDGEMENT}

The authors would like to acknowledge the support from RSUD Kota Yogyakarta staff and respondent, for their support and encouragement while preparing this research and paper.

\section{BIBLIOGRAPHY}

1. KARS. (2017). Standar Nasional Akreditasi Rumah Sakit Efektif 1 Januari 2018. Standar Nasional Akreditasi Rumah Sakit.

2. Adisasmito, W. (2008). Kesiapan Rumah Sakit Dalam Menghadapi Globalisasi. Case Studi: Analisis Kesehatan. Fakulatas Kesehatan Masyarakat Universitas Indonesia.

3. Permenkes R.I No 1691. (2011). Peraturan Menteri Kesehatan Republik Indonesia Nomor 1691 Tahun 2011 Tentang Keselamatan Pasien Rumah Sakit. PERMENKES.

4. Kars. (2012). Komisi Akreditasi Rumah Sakit. Kars.

5. Mulyana, D. S. (2013). Analisis Penyebab Insiden Keselamatan Pasien oleh Perawat Di Unit Rawat Inap RS X Jakarta. In Kesehatan Masyarakat.
6. Yudhawati, D., \& Listiowati, E. (2015). EVALUASI PENERAPAN IDENTIFIKASI PASIEN DI BANGSAL RAWAT INAP RSI SITI AISYAH MADIUN. Jurnal Medicoeticolegal Dan Manajemen Rumah Sakit.

7. Setiowati, D. (2010). Hubungan Kepemimpinan Head Ners Dengan Penerapan Budaya Keselamatan Pasien Oleh Perawat Pelaksana di RSUPN DR. Cipto Mangunkusumo.

8. Umaternate, T., Kumaat, L., \& Mulyadi, N. (2015). HUBUNGAN PELAKSANAAN IDENTIFIKASI PASIEN SECARA BENAR DENGAN KEPUASAN PASIEN DI INSTALASI GAWAT DADURAT (IGD) RSUP PROF. DR. R. D. KANDOU MANADO. Jurnal Keperawatan UNSRAT.

9. Sundoro, T., Elsye, ;, Rosa, M., Risdiana, I., \& Korespondensi, P. (2016). Evaluasi Pelaksanaan Sasaran Keselamatan Pasien Sesuai Akreditasi Rumah Sakit Versi 2012 di Rumah Sakit Khusus Ibu dan Anak PKU Muhammadiyah Kotagede Yogyakarta. Jurnal Medicoeticolegal Dan Manajemen Rumah Sakit.

10. Saraswati, G. (2014). Hubungan Supervisi Pelayanan Keperawatan Dengan Penerapan Budaya Keselamatan Pasien oleh Perawat Pelaksana di RSUP Sanglah Denpasar.

11. Budihardjo, A. (2008). Pentingnya Safety Culture Di Rumah Sakit: Upaya Meminimalkan Adverse Events. Integritas - Jurnal Manajemen Bisnis.

12. Anggraini, D., Hakim, L., \& Widjiati Imam, C. (2014). Evaluasi Pelaksanaan Sistem Identifikasi Pasien di Instalasi Rawat Inap Rumah Sakit. Jurnal Kedokteran Brawijaya. https://doi.org/10.21776/ub.jkb.2014.028. 01.32

13. Notoatmodjo, S. (2012). Promosi Kesehatan dan Perilaku Kesehatan. In Journal of Chemical Information and Modeling. https://doi.org/10.1017/CBO9781107415 324.004 
14. Nursalam. (2011). Manajemen Keperawatan Aplikasi dalam Praktik Keperawatan Profesional Edisi 3. In Salemba Medika.

15. El-Jardali, F., Sheikh, F., Garcia, N. A., Jamal, D., \& Abdo, A. (2014). Patient safety culture in a large teaching hospital in Riyadh: Baseline assessment, comparative analysis and opportunities for improvement. BMC Health Services Research. https://doi.org/10.1186/14726963-14-122

16. Hutahaean, S. (2018) PENGEMBANGAN FUNGSI DAN PERAN KEPALA RUANGAN DALAM PENCEGAHAN DAN PENGENDALIAN INFEKSI DI RUMAH SAKIT X. JURNAL
AKADEMI KEPERAWATAN

HUSADA KARYA JAYA, 4(1).

17. undang-undang RI. (2009). UNDANGUNDANG RI NO 44 TAHUN 2009 TENTANG RUMAH SAKIT. Rumah Sakit.

18. Cahyono, J. B. (2008). Membangun budaya keselamatan pasien dalam praktik kedokteran. Yogyakarta: Kanisius.

19. Yusuf, M. (2017). Penerapan Patient Safety Di Ruang Rawat Inap Rumah Sakit Umum Daerah Dr. Zainoel Abidin Patient Safety Implementation In Ward Of Dr. Zainoel Abidin General Hospital. Jurnal Ilmu Keperawatan, 5(1), 1-6.

20. Wibowo. (2016). Budaya Organisasi. Edisi kedua Cetakan Keempat, PT. Rajawali pers, Jakarta. 